\title{
Directly grown nanostructured electrodes for high- power and high-stability alkaline nickel/bismuth batteries
}

\author{
Deliang $\mathrm{Ba}^{1}$, Yuanyuan $\mathrm{Li}^{12^{2 *}}$, Yunfei Sun ${ }^{1}$, Zaiping $\mathrm{Guo}^{2^{*}}$ and Jinping $\mathrm{Liu}^{3^{*}}$
}

\begin{abstract}
Bismuth oxide $\left(\mathrm{Bi}_{2} \mathrm{O}_{3}\right)$ has received great attention as an anode material for alkaline nickel/bismuth $(\mathrm{Ni} /$ Bi) batteries due to its high theoretical capacity and easy preparation. However, the generally poor conductivity of metal oxides and the instability of $\mathrm{Bi}_{2} \mathrm{O}_{3}$ during cycling severely limit the device performance. Herein, we present the use of directly grown $\mathrm{Bi}_{2} \mathrm{O}_{3}$ nanoflake film with kinetic advantages as the anode for $\mathrm{Ni} / \mathrm{Bi}$ batteries. Particularly, glucose-derived carbon is integrated onto the surfaces of nanoflakes, which not only enhances the electron transfer but also buffers the conversion-reaction induced volume expansion of $\mathrm{Bi}_{2} \mathrm{O}_{3}$, helping maintaining the cycling stability of the film. The resulting $\mathrm{Bi}_{2} \mathrm{O}_{3} @ \mathrm{C}$ electrode exhibits high specific capacity, excellent rate performance (can be charged within $6.7 \mathrm{~s}$ ), and good cycle stability $(\sim 1,200$ times; fading rate of only $0.011 \%$ per cycle). When assembled with a nickel oxide $(\mathrm{NiO})$ nanosheet array cathode in basic electrolyte, a fully binder-free $\mathrm{Ni} / \mathrm{Bi}$ battery is obtained, which delivers maximum energy and power densities of $34.29 \mathrm{~W} \mathrm{~h} \mathrm{~kg}^{-1}$ and $12,159.8 \mathrm{~W} \mathrm{~kg}^{-1}$, respectively, and good cycling performance. The power density is even much superior to that of many hybrid/asymmetric supercapacitors. Our work suggests a new generation of thin-film Ni/Bi batteries for potential high-power electronic applications.
\end{abstract}

Keywords: $\mathrm{Bi}_{2} \mathrm{O}_{3}$, binder-free, high power, high stability, alkaline rechargeable battery

\section{INTRODUCTION}

With the urgent need for the development of clean and renewable energy due to the constant consumption of traditional fossil fuels, safe and efficient energy storage devices, especially rechargeable batteries, have attracted great attention in recent years [1,2]. Lithium-ion batteries with high energy density and long service life are the most successful energy storage devices [3-5]. However, the low reserves of lithium resources lead to higher costs, and a series of security issues arising from the flammable organic electrolytes limit their extensive applications in future [6,7]. Owing to remarkable advantages of high ionic conductivity of electrolytes, good safety, and low cost over organic counterparts, aqueous rechargeable batteries (ARBs) represent an emerging class of new energy storage devices. Particularly, aqueous rechargeable nickel/metal batteries are one of the most promising ARBs for their high energy density, good rate capability and abundant resources $[8,9]$. Up to now, there are several nickel/metal battery systems that have been reported, such as nickel-cadmium (Ni/Cd), nickel-metal hydride $(\mathrm{Ni} / \mathrm{MH})$, nickel-cobalt $(\mathrm{Ni} / \mathrm{Co})$, nickel-iron $(\mathrm{Ni} / \mathrm{Fe})$, nickel-zinc $(\mathrm{Ni} / \mathrm{Zn})$, etc [10-13]. Although these achievements are indeed impressive, the rate performance and cycle life of most reported nickel/metal batteries are yet unsatisfactory, which are basically caused by the intrinsically poor conductivity and sluggish electrochemical kinetics of the metal oxide/hydroxide electrodes. In addition, the anodic reaction (such as $\mathrm{Co}, \mathrm{Fe}$ and $\mathrm{Zn}$ ) in most of these nickel/metal batteries suffers from huge phase transformation, leading to quite limited cycling lifetime. Therefore, it is still challenging to develop advanced anode materials for high-rate and long-stability nickel/metal rechargeable batteries.

Bismuth oxide $\left(\mathrm{Bi}_{2} \mathrm{O}_{3}\right)$ is well-known as a promising transition metal oxide due to its low cost and toxicity, high oxygen conducting, and good photocatalytic prop-

\footnotetext{
${ }^{1}$ School of Optical and Electronic Information, Huazhong University of Science and Technology, Wuhan 430074, China

${ }^{2}$ Engineering Materials Institute, School of Mechanical, Materials \& Mechatronics Engineering, University of Wollongong, Wollongong 2500, Australia

${ }^{3}$ State Key Laboratory of Advanced Technology for Materials Synthesis and Processing, Wuhan University of Technology, Wuhan 430070, China

* Corresponding authors (emails: liyynano@hust.edu.cn (Li Y); zguo@uow.edu.au (Guo Z); liujp@whut.edu.cn (Liu J))
} 
erties $[14,15]$. Therefore, it has already been widely used as catalysts, optical materials and gas sensors, etc. Recently, $\mathrm{Bi}_{2} \mathrm{O}_{3}$ has also been investigated as potential anode material for electrochemical energy storage devices. For example, $\mathrm{Bi}_{2} \mathrm{O}_{3}$ thin film electrode, synthesized by electrodeposition, exhibited a specific capacitance of $98 \mathrm{~F} \mathrm{~g}^{-1}$ [15]. This work demonstrated the potential of $\mathrm{Bi}_{2} \mathrm{O}_{3}$ in aqueous energy storage, but only achieved small capacitance, probably due to the semiconducting nature of $\mathrm{Bi}_{2} \mathrm{O}_{3}$. An effective way to increase the electrical conductivity or enhance the charge transfer of $\mathrm{Bi}_{2} \mathrm{O}_{3}$ electrodes is the design of nanostructured composition with conductive materials such as graphene, mesoporous carbon and titania nanotube, etc. [14]. Hu et al. [16] have reported the supercapacitor behavior of $\mathrm{Bi}_{2} \mathrm{O}_{3} /$ graphene. They obtained a specific capacitance of $255 \mathrm{~F} \mathrm{~g}^{-1}$ at a current density of $1 \mathrm{~A} \mathrm{~g}^{-1}$. Yuan et al. [17] prepared worm-like mesoporous carbon@ $\mathrm{Bi}_{2} \mathrm{O}_{3}$ composites electrode material, which showed good electrochemical performance with the capacitance reaching $386 \mathrm{~F} \mathrm{~g}^{-1}$. Despite the great potentials, $\mathrm{Bi}_{2} \mathrm{O}_{3}$ was mainly utilized for developing hybrid supercapacitor in these literatures. $\mathrm{Bi}_{2} \mathrm{O}_{3}$, involving in the redox reaction within the potential range of $-1.2-0 \mathrm{~V}(v s . \mathrm{Hg} / \mathrm{HgO})$ in aqueous alkaline electrolyte, is also anticipated to be used as anode of nickel/metal batteries [18]. Lu et al. [19] developed novel Bi hierarchical nanostructures as advanced anode materials; and in situ Raman spectroscopy revealed the highly reversible electrochemical reaction between $\mathrm{Bi}^{0}$ and $\mathrm{Bi}^{3+}$ for the $\mathrm{Bi}$ 200 electrode in $\mathrm{KOH}$ electrolyte. A Ni/Bi battery was designed by Yang et al. [20] using the $\mathrm{Bi}_{2} \mathrm{O}_{3}$ /graphene sheet (GS) hybrid as negative electrode and $\mathrm{Ni}(\mathrm{OH})_{2} / \mathrm{GS}$ as positive electrode, which delivered a high power density of $2,609 \mathrm{~W} \mathrm{~kg}^{-1}$ and cycling capability of 200 times ( $60 \%$ retention). The authors further constructed an alternative $\mathrm{Ni} / \mathrm{Bi}$ battery with bismuth basic carbonate as the anode; $77 \%$ of the initial capacity can be kept after 80 cycles [21]. As another example, Wang et al. [22] reported a $\mathrm{Bi}_{2} \mathrm{O}_{3}$ electrode with a high capacity of $>200 \mathrm{~mA} \mathrm{~h} \mathrm{~g}^{-1}$ but poor capacity retention (merely $87 \%$ after 20 chargedischarge cycles). Based on the above survey, the research on $\mathrm{Ni} / \mathrm{Bi}$ batteries still lag far behind that of other nickel/ metal batteries, and in particular, it is highly necessary to boost the cycle performance while maintaining other electrochemical attributes.

Herein, we synthesize $\mathrm{Bi}_{2} \mathrm{O}_{3}$ nanoflake film electrode directly on current collector via a simple hydrothermal process for advanced $\mathrm{Ni} / \mathrm{Bi}$ batteries. As shown in Scheme 1 , the interconnected nanoflakes form a three-dimensional (3D) porous structure that affords more sites for

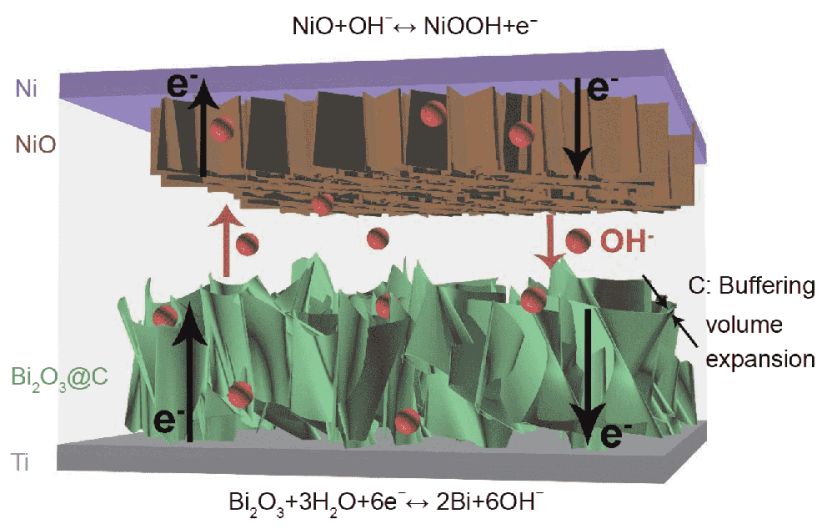

Scheme 1 Illustration of the fully binder-free $\mathrm{Ni} / \mathrm{Bi}$ battery. The cathode employs $\mathrm{NiO}$ nanosheet array and the anode utilizes $\mathrm{Bi}_{2} \mathrm{O}_{3} @ \mathrm{C}$ nanoflake film. Electrolyte is $3 \mathrm{~mol} \mathrm{~L}^{-1} \mathrm{NaOH}$.

electrolyte penetration, dramatically enhancing redox kinetics at high charge/discharge rates. In particular, a simple glucose adsorption and carbonization allow the nanoflake surface to be modified with nanocarbon, which not only further enhances the electrical conductivity but also buffers the volume expansion of $\mathrm{Bi}_{2} \mathrm{O}_{3}$ during redox reaction, improving electrode cycle stability. The resulting $\mathrm{Bi}_{2} \mathrm{O}_{3} @ \mathrm{C}$ anode delivers $40 \%$ of the initial capacity even with the current density increased 32 times from 0.83 to $26.67 \mathrm{~A} \mathrm{~g}^{-1}$, indicative of excellent rate capability. When combining the $\mathrm{Bi}_{2} \mathrm{O}_{3} @ \mathrm{C}$ film anode with hydrothermally grown $\mathrm{NiO}$ nanosheet array cathode, we construct a fully binder- and additive-free alkaline rechargeable $\mathrm{Ni} / \mathrm{Bi}$ battery. The device delivers maximum energy and power densities of $34.29 \mathrm{~W} \mathrm{~h} \mathrm{~kg}^{-1}$ and $12,159.8 \mathrm{~W} \mathrm{~kg}^{-1}$, respectively. It also demonstrates long-term cycling stability with $83 \%$ of the initial capacity retained after 1,000 cycles. This work presents an opportunity to develop high-performance thin-film Ni/Bi batteries.

\section{EXPERIMENTAL SECTION}

\section{Synthesis}

All reagents were of analytical grade and used directly without any purification. To prepare $\mathrm{Bi}_{2} \mathrm{O}_{3} @ \mathrm{C}$ anode, typically, Ti foil as current collector was cleaned by sonication in ethanol and deionized water, successively. Then, it was put into a sealed Teflon-lined stainless vessel containing a mixed solution of $2.07 \mathrm{~g} \mathrm{Bi}\left(\mathrm{NO}_{3}\right)_{3} \cdot 5 \mathrm{H}_{2} \mathrm{O}$, $0-2.5 \mathrm{~g}$ glucose $\left(0-0.77 \mathrm{~mol} \mathrm{~L}^{-1}\right), 6 \mathrm{~mL}$ ethylene glycol and $12 \mathrm{~mL}$ alcohol. The vessel was then heated at $160^{\circ} \mathrm{C}$ for $5 \mathrm{~h}$. After being cooled down to room temperature, the $\mathrm{Ti}$ foil was picked up, washed with acetone and 
deionized water, and finally dried at $60^{\circ} \mathrm{C}$ in air.

For the synthesis of $\mathrm{NiO}$ cathode, the nickel foam was firstly cleaned by sonication in ethanol and deionized water, successively. Then, it was put into a sealed Teflonlined stainless vessel containing a mixed solution of $4.35 \mathrm{~g}$ $\mathrm{Ni}\left(\mathrm{NO}_{3}\right)_{2}, 0.108 \mathrm{~g}$ urea, $0.222 \mathrm{~g} \mathrm{NH}_{4} \mathrm{~F}$ and $15 \mathrm{~mL} \mathrm{H}_{2} \mathrm{O}$, which was subsequently heated at $160^{\circ} \mathrm{C}$ for $10 \mathrm{~h}$. After the hydrothermal reaction, the nickel foam covered with nickel-based hydroxides was rinsed with deionized water and dried in a vacuum oven, followed by annealing in $\mathrm{Ar}$ atmosphere at $400^{\circ} \mathrm{C}$ for $1 \mathrm{~h}$.

\section{Morphology and structure characterizations}

The morphologies and crystalline structure of as-synthesized products were characterized by scanning electron microscope (SEM, JSM-6700F, and $5 \mathrm{kV}$ ) with energy-dispersive X-ray spectroscopy (EDS), transmission electron microscope (TEM, JEM-2010FEF, $200 \mathrm{kV}$ ) and X-ray diffractometer (XRD, Bruker D-8 Avance, $\mathrm{Cu}$ $\mathrm{Ka}$ ). X-ray photoelectron spectroscopy (XPS) measurement was performed on a VG ESCALAB 250 spectrometer (Thermo Electron, UK) with monochromatic Al $\mathrm{Ka}(1,486.6 \mathrm{eV})$ irradiation. The mass of active materials was measured on an AX/MX/UMX Balance (METTLER TOLEDO, maximum $=9.9 \mathrm{~g}, d=0.001 \mathrm{mg}$ ).

\section{Electrochemical measurements}

Electrochemical measurements were performed on an electrochemical workstation $(\mathrm{CHI} 760 \mathrm{C}, \mathrm{CH}$ Instruments Inc, Shanghai) in cyclic voltammeter (CV) and galvanostatic charge-discharge (GCD) modes with a three-electrode system in $3 \mathrm{~mol} \mathrm{~L}^{-1} \mathrm{NaOH}$ aqueous electrolyte. The reference electrode and the counter electrode were $\mathrm{Hg} /$ $\mathrm{HgO}$ electrode and platinum foil, respectively. The $\mathrm{Bi}_{2} \mathrm{O}_{3} @ \mathrm{C}$ film (mass loading: $2.4 \mathrm{mg} \mathrm{cm}^{-2}$ ) or the $\mathrm{NiO}$ array $\left(1.1 \mathrm{mg} \mathrm{cm}^{-2}\right)$ was used directly as the working electrode. For the full-cell Ni/Bi battery testing, $\mathrm{Bi}_{2} \mathrm{O}_{3} @ \mathrm{C}$ film and the $\mathrm{NiO}$ array were assembled face to face in coin cell and used as negative electrode and positive electrode, respectively. One piece of cellulose paper was infiltrated with $3 \mathrm{~mol} \mathrm{~L}^{-1} \mathrm{NaOH}$ and utilized as the separator. Electrochemical impedance spectroscopy (EIS) was measured by an $\mathrm{AC}$ voltage with $5 \mathrm{mV}$ amplitude in a frequency range from $0.01 \mathrm{~Hz}$ to $100 \mathrm{kHz}$.

The energy and power densities of the $\mathrm{Ni} / \mathrm{Bi}$ battery were calculated based on $E=\int I V(t) \mathrm{d} t$ and $P=E / \Delta t$, where $I$ is the discharging current density $\left(\mathrm{A} \mathrm{g}^{-1}\right), V(t)$ is discharging voltage at $t, \mathrm{~d} t$ is time differential, and $\Delta t$ is the total discharging time. The mass was based on the active materials at both the positive and negative electrodes.

\section{RESULTS AND DISCUSSION}

\section{$\mathrm{Bi}_{2} \mathrm{O}_{3}$-based negative electrode}

Fig. 1a shows typical SEM image of the pristine $\mathrm{Bi}_{2} \mathrm{O}_{3}$ film, which is about $400 \mathrm{~nm}$ in thickness (inset in Fig. 1a) and consists of many nanoflakes. The pristine nanoflakes were synthesized without the addition glucose. They lie on the Ti current collector foil and are interconnected with each other, forming nanoflakes architecture with an open framework. It is noteworthy that such a structure will make the nanoflake surfaces efficiently exposed to the electrolyte when used as an electrode for rechargeable batteries [23], facilitating the transport and migration of ions and thus being beneficial to the electrochemical kinetics. As shown in Fig. 1b, the composition of the nanoflakes is confirmed by the XRD pattern. In addition to the peaks from the Ti substrate (marked with \#), all the diffraction peaks can be well indexed to $\delta-\mathrm{Bi}_{2} \mathrm{O}_{3}$ (JCPDS card No. 27-52). No other peaks are observed, revealing high purity of the sample. To improve the electrical conductivity, the $\mathrm{Bi}_{2} \mathrm{O}_{3}$ nanoflakes were modified with carbon by in-situ hydrothermal carbonization of glucose. This process can introduce nanoscale carbon painting on the electrode nanostructures [23]. Fig. 1c shows SEM image of the resulting $\mathrm{Bi}_{2} \mathrm{O}_{3} @ \mathrm{C}$ film, from which we can see that the overall structure is basically unchanged. XRD pattern in Fig. 1d reveals that all the diffraction peaks match well with $\alpha-\mathrm{Bi}_{2} \mathrm{O}_{3}$ (JCPDS card No. 27-53), except those from the $\mathrm{Ti}$ (marked with \#). Although carbon cannot be directly observed from XRD, the EDS elemental mapping (inset in Fig. 1c) unambiguously indicates the uniform distribution of carbon within the film. Fig. 1e shows the XPS survey of the electrode film. In the full spectrum, the intensive $C 1$ s peak further indicates the presence of carbon. In the high-resolution spectrum of Bi 4f, the two strong peaks located at 159.1 and $164.5 \mathrm{eV}$ correspond to the $\mathrm{Bi} 4 \mathrm{f}_{7 / 2}$ and $4 \mathrm{f}_{5 / 2}$ signals, respectively. In addition, the $\mathrm{Bi} 4 \mathrm{f}_{7 / 2}$ peak can be deconvoluted into two peaks of $\mathrm{Bi}^{3+}(159.3 \mathrm{eV})$ and $\mathrm{Bi}^{2+}$ $(158.7 \mathrm{eV})[24,25]$. It is noted that XPS is a surface sensitive technology with penetration depth of only a few nanometers; thus the appearance of $\mathrm{Bi}^{2+}$ can be attributed to the partial reduction of $\mathrm{Bi}^{3+}$ to $\mathrm{Bi}^{2+}$ by carbon on the surface. TEM analysis was utilized to further confirm the composition of the nanoflakes, as displayed in Fig. 1f. A lattice fringe of ca. $0.24 \mathrm{~nm}$ is observed, corresponding to the $(-113)$ plane of monoclinic $\alpha-\mathrm{Bi}_{2} \mathrm{O}_{3}$. It is clear that the crystalline structure of $\mathrm{Bi}_{2} \mathrm{O}_{3}$ is overlapped or surrounded with low-crystalline carbon, further indicating the hybrid structure. 

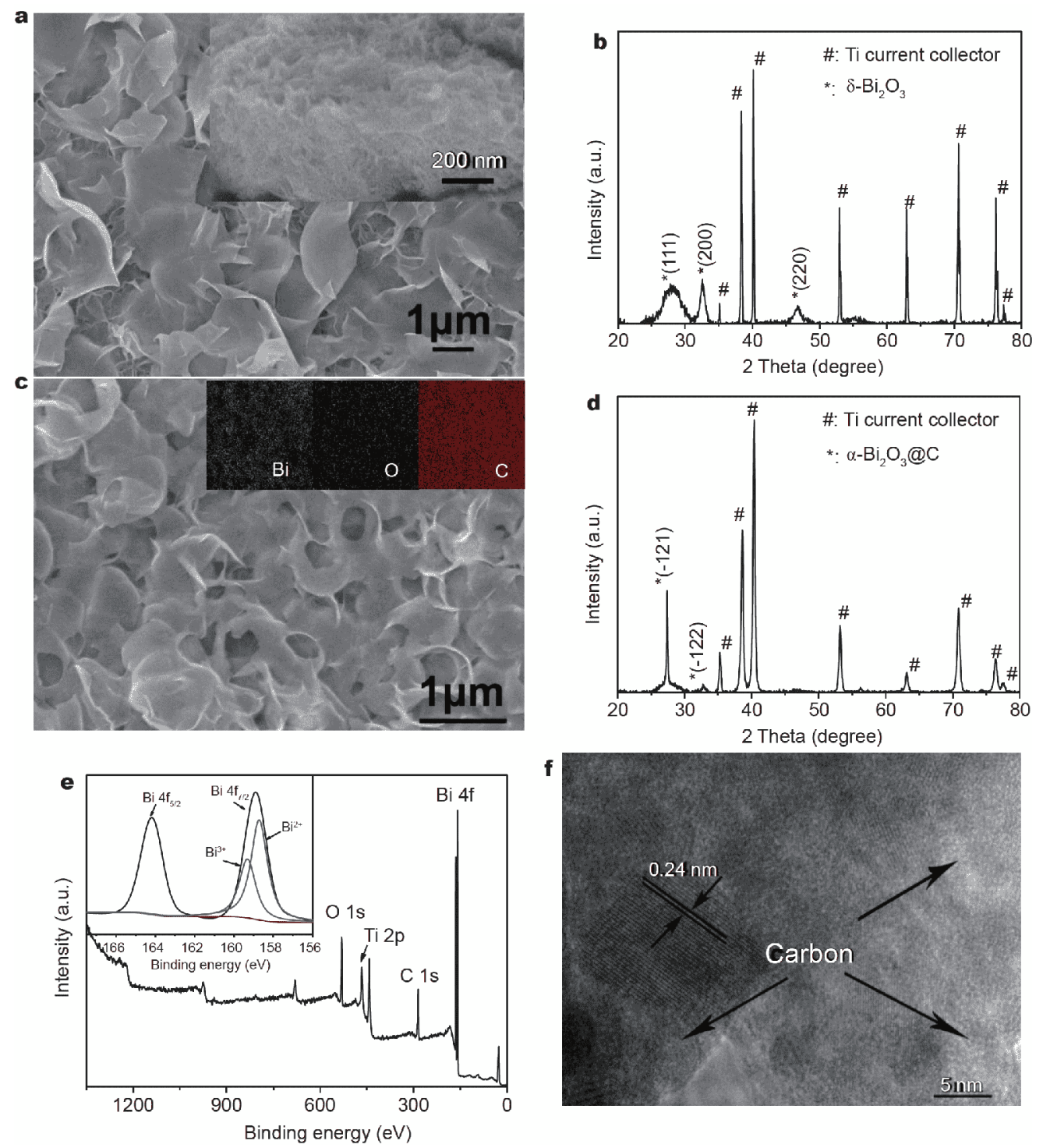

Figure 1 (a) Top-view and cross-sectional SEM images and (b) XRD pattern of $\mathrm{Bi}_{2} \mathrm{O}_{3}$. (c) SEM image (inset is EDS elemental mapping results), (d) XRD pattern, (e) XPS full spectrum (inset is the high-resolution spectrum of Bi 4f) and (f) TEM image of $\mathrm{Bi}_{2} \mathrm{O}_{3} @ \mathrm{C}$.

Electrochemical tests of the individual electrode were performed in a three-electrode configuration using a $3 \mathrm{~mol} \mathrm{~L}^{-1} \mathrm{NaOH}$ aqueous electrolyte. The effect of carbon content on the electrochemical performance was studied by comparatively examining film samples attained with glucose concentration ranging from 0 to $0.77 \mathrm{~mol} \mathrm{~L}^{-1}$. It can be seen from Fig. $2 a$ that the capacity of the electrode gradually increases with increasing the glucose dosage from 0 to $0.308 \mathrm{~mol} \mathrm{~L}^{-1}$. This means that higher capacity has been achieved after proper carbon modification, probably due to the enhancement of the electrical conductivity while not preventing $\mathrm{OH}^{-}$diffusion into the inner region to participate in the redox reaction [26]. With $0.308 \mathrm{~mol} \mathrm{~L}^{-1}$ glucose during the hydrothermal process, the obtained electrode delivers a capacity of $\sim 120 \mathrm{~mA} \mathrm{~h} \mathrm{~g}^{-1}$ at $5 \mathrm{mV} \mathrm{s}^{-1}$. Nevertheless, we should be aware of that too much carbon modification is not helpful, because in this case the ion diffusion into $\mathrm{Bi}_{2} \mathrm{O}_{3}$ cannot be guaranteed and thus the faradaic reaction cannot be manifested. Fig. 2a also shows that continuing to increase the dosage of glucose from 0.308 to $0.77 \mathrm{~mol} \mathrm{~L}^{-1}$ results in a decrease in the capacity, indicative of the diffusion limitation effect. EIS results are further utilized to support the above analysis, as shown in 

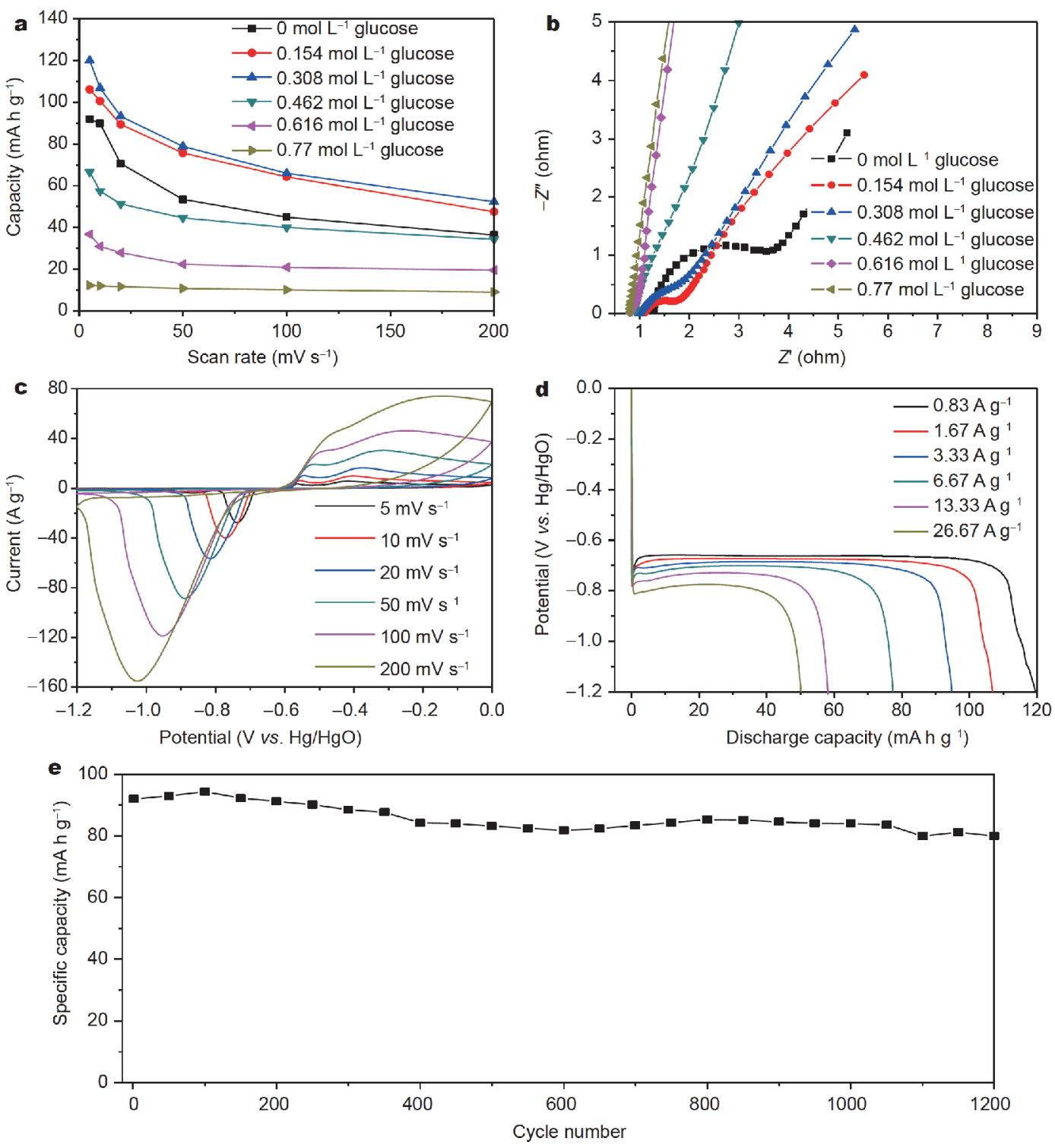

Figure 2 (a) The capacity as a function of scan rate and (b) EIS spectra of $\mathrm{Bi}_{2} \mathrm{O}_{3} @ \mathrm{C}$ electrodes fabricated from different glucose concentrations. (c) CVs, (d) charge-discharge curves and (e) cycling performance of $\mathrm{Bi}_{2} \mathrm{O}_{3} @ \mathrm{C}$ anode. The glucose concentration of (c-e) is $0.308 \mathrm{~mol} \mathrm{~L}^{-1}$.

Fig. 2b. All the EIS curves exhibit a straight line in the low-frequency region and a semicircular loop in the highfrequency region. The diameter of the semicircular loop represents the charge transfer resistance $\left(R_{\mathrm{ct}}\right)$ at the electrode-electrolyte interface, while the intercept on the $x$-axis at the high frequency represents the bulk electrolyte solution resistance and intrinsic resistance of the active material $\left(R_{\mathrm{s}}\right)$. As can be seen, $R_{\mathrm{s}}$ and $R_{\mathrm{ct}}$ indeed decreases with the carbon coating and the gradient of the sloping line of the $\mathrm{Bi}_{2} \mathrm{O}_{3} @ \mathrm{C}$ electrode is generally larger than that of $\mathrm{Bi}_{2} \mathrm{O}_{3}$ electrode. These results clearly indicate higher electrical conductivity and better electroactivity of the electrode after rational carbon decoration, which are highly required for full cell application. We next choose the film electrode synthesized with $0.308 \mathrm{~mol} \mathrm{~L}^{-1}$ glucose for the following discussions.

Fig. 2c illustrates the CVs of the $\mathrm{Bi}_{2} \mathrm{O}_{3} @ \mathrm{C}$ electrode at various scan rates. The charge storage mechanism can be ascribed in the following reaction involving the $\mathrm{OH}^{-}$in the electrolyte [27-29]: $\mathrm{Bi}_{2} \mathrm{O}_{3}+3 \mathrm{H}_{2} \mathrm{O}+6 \mathrm{e}^{-} \leftrightarrow 2 \mathrm{Bi}+6 \mathrm{OH}^{-}$. Since the redox reaction of $\mathrm{Bi}_{2} \mathrm{O}_{3}$ is a diffusion-controlled process, the rate performance should be mainly dependent on the charge and mass transfer kinetics. Good rate performance can be expected for the $\mathrm{Bi}_{2} \mathrm{O}_{3}$ nanoflakes 

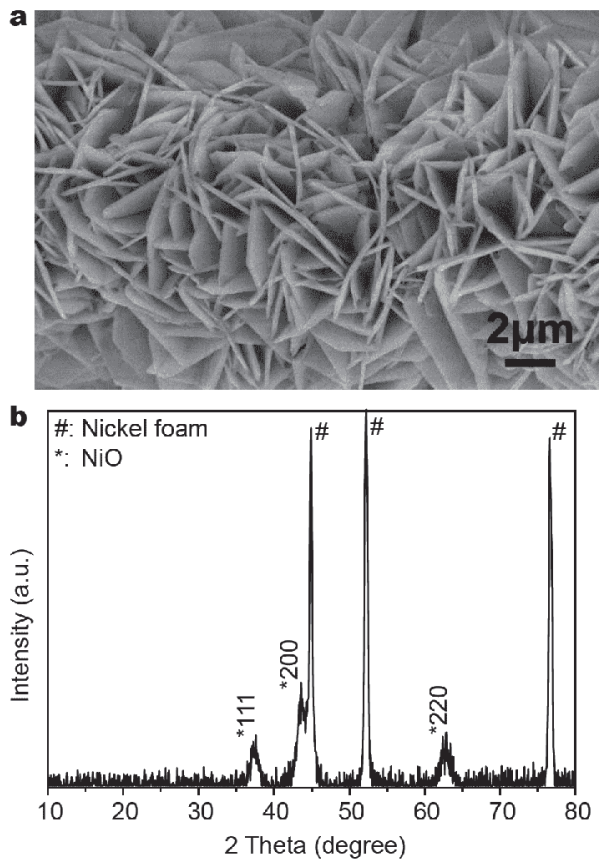

Figure 3 (a) SEM image and (b) X-ray diffraction pattern of $\mathrm{NiO}$ cathode.

well modified with conductive carbon, as in such a structure the ion diffusion pathway is short and electron transport is rapid. As evidenced in Fig. 2c, the CV profiles consist of a pair of strong faradaic redox peaks, and the peak polarization does not obviously change with the scan rate increasing from 5 to $200 \mathrm{mV} \mathrm{s}^{-1}$. The galvanostatic discharge behaviors at different current densities for the $\mathrm{Bi}_{2} \mathrm{O}_{3} @ \mathrm{C}$ electrode are presented in Fig. 2d. It delivers a high capacity of $120 \mathrm{~mA} \mathrm{~h} \mathrm{~g}^{-1}$ at $0.83 \mathrm{~A} \mathrm{~g}^{-1}$. Even at a current density as high as $26.67 \mathrm{~A} \mathrm{~g}^{-1}$ (charging within $6.7 \mathrm{~s}), \sim 40 \%$ of its initial capacity can still be retained, demonstrating its superior rate capability. The potential plateaus around $-0.70 \mathrm{~V}$ is ascribed to be the redox transformation from $\mathrm{Bi}(\mathrm{III})$ to $\mathrm{Bi}(0)$, characteristic of a typical battery-type behavior. This plateau is merely shifted to around $-0.8 \mathrm{~V}$ with 32 times increase of the current density, further demonstrating fast redox kinetics of the $\mathrm{Bi}_{2} \mathrm{O}_{3} @ \mathrm{C}$ nanoflake film electrode [30]. The longterm cycling stability of the $\mathrm{Bi}_{2} \mathrm{O}_{3} @ \mathrm{C}$ electrode was examined at $20 \mathrm{mV} \mathrm{s}^{-1}$ and the result is displayed in Fig. $2 \mathrm{e}$. It is observed that the electrode can keep $87 \%$ of initial capacity over 1,200 cycles and the fading rate is only $0.011 \%$ per cycle, indicative of excellent stability. All the above results clearly reveal the exceptional capability of the $\mathrm{Bi}_{2} \mathrm{O}_{3} @ \mathrm{C}$ nanoflake electrode to meet the requirements of good rate capability and long cycling life, which are crucial factors for the high-performance energy sto- rage devices.

\section{$\mathrm{NiO}$ positive electrode}

As the positive electrode for assembling $\mathrm{Ni} / \mathrm{Bi}$ battery, $\mathrm{NiO}$ was also directly grown on current collector by a simple hydrothermal method. Fig. 3a shows the SEM image of the as-synthesized $\mathrm{NiO}$ on nickel foam substrate. It can be seen that $\mathrm{NiO}$ was grown with nanosheet structure and are interconnected with each other to form a 3D network, which would ensure effective infiltration of electrolyte and the rapid diffusion of ions (Schematic 1). To verify the composition of the nanosheets, XRD analysis was carried out (Fig. 3b). In addition to the peaks from the nickel foam substrate (marked with \#, JCPDS card No.3-1051), all other diffraction peaks can be well indexed to NiO (JCPDS card No.1-1239).

Electrochemical measurements of the $\mathrm{NiO}$ electrode were performed in a three-electrode configuration using a $3 \mathrm{~mol} \mathrm{~L}^{-1} \mathrm{NaOH}$ aqueous electrolyte. As illustrated in Fig. 4 a, a pair of peaks is observed in the potential range of $0-0.7 \mathrm{~V}$ for $\mathrm{CV}$ curves at different scan rates, which arise from the following redox reaction of $\mathrm{Ni}(\mathrm{II}) / \mathrm{Ni}(\mathrm{III})$ associated with $\mathrm{OH}^{-}$[31-33]: $\mathrm{NiO}+\mathrm{OH}^{-} \leftrightarrow \mathrm{NiOOH}+\mathrm{e}^{-}$. The corresponding rate capability is further shown in Fig. 4 b. As can be seen, $\mathrm{NiO}$ electrode delivers specific capacities of $263,207,166,126$, and $94 \mathrm{~mA} \mathrm{~h} \mathrm{~g}^{-1}$ at the scan rate of $5,10,20,50$, and $100 \mathrm{mV} \mathrm{s}^{-1}$, respectively, demonstrating good rate capability. The discharge plateaus of $\mathrm{NiO}$ electrode can be identified in the galvanostatic discharge curves in Fig. 4c. Despite that the plateau polarization can be observed with the increase of the discharging current, good plateau can always be detected, which indicates excellent redox behavior of $\mathrm{NiO}$. In ad-
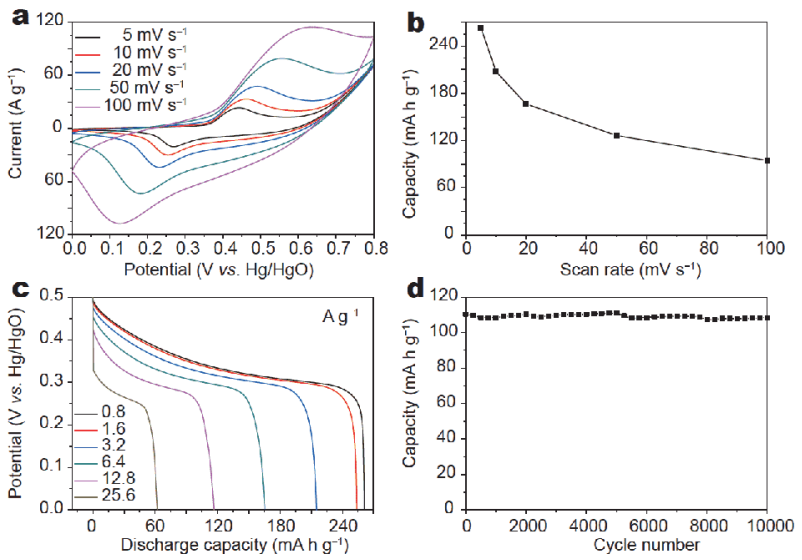

Figure 4 (a) CV curves, (b) capacity as a function of scan rate, (c) discharge curves at various current densities and (d) cycling performance of $\mathrm{NiO}$ cathode. 

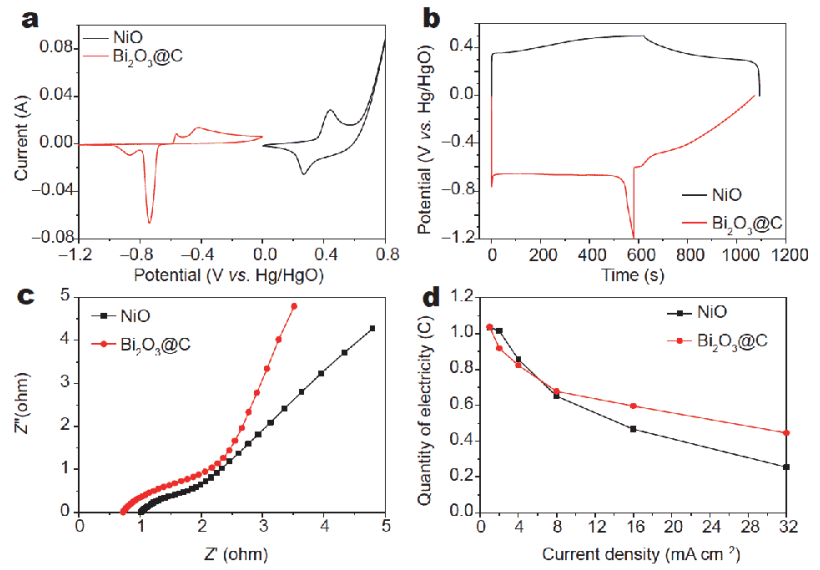

Figure 5 (a) CV curves of matched $\mathrm{NiO}$ cathode and $\mathrm{Bi}_{2} \mathrm{O}_{3} @ \mathrm{C}$ anode at $5 \mathrm{mV} \mathrm{s}^{-1}$. (b) GCD voltage profiles for the positive and negative electrodes at $1 \mathrm{~mA} \mathrm{~cm}^{-2}$. (c) Nyquist plots of $\mathrm{NiO}$ and $\mathrm{Bi}_{2} \mathrm{O}_{3} @ \mathrm{C}$. (d) The stored charges of the electrodes at different current densities.

dition, the $\mathrm{NiO}$ electrode exhibits ultralong cycling stability with little capacity decay over 10,000 cycles, as shown in Fig. 4d.

\section{Assembly and electrochemical performance of $\mathrm{Ni} / \mathrm{Bi}$ battery}

The $\mathrm{Bi}_{2} \mathrm{O}_{3} @ \mathrm{C}$ negative electrode material is found to have higher mass loading than that of $\mathrm{NiO}$ positive electrode, which exactly balances the larger specific capacity of the positive electrode of $\mathrm{NiO}$. Fig. 5a exhibits typical CV curves of the balanced $\mathrm{NiO}$ and $\mathrm{Bi}_{2} \mathrm{O}_{3} @ \mathrm{C}$ electrodes at $5 \mathrm{mV} \mathrm{s}^{-1}$ in $3 \mathrm{~mol} \mathrm{~L}^{-1} \mathrm{NaOH}$ electrolyte. Both the $\mathrm{CV}$ curves consist of a pair of strong redox peaks, indicative of the faradaic redox mechanism [34]. The oxidization and reduction potential peaks of $\mathrm{NiO}$ positive electrode are observed at 0.44 and $0.27 \mathrm{~V}$, respectively; Meanwhile, the redox peaks of $\mathrm{Bi}_{2} \mathrm{O}_{3} @ \mathrm{C}$ negative electrode located at -0.45 and $-0.78 \mathrm{~V}$. In such a case, a Ni/Bi battery can be readily constructed. Fig. $5 b$ shows the GCD profiles of both the positive and negative electrodes at $1 \mathrm{~mA} \mathrm{~cm}^{-2}$ after assembly into a full-cell $\mathrm{Ni} / \mathrm{Bi}$ battery. During the charging process, $\mathrm{NiO}$ is oxidized into $\mathrm{NiOOH}$ and $\mathrm{Bi}_{2} \mathrm{O}_{3}$ is reduced into $\mathrm{Bi}$; when discharging, the process reverses. To further investigate the electrochemical impedance behaviors of both the positive and negative electrodes, the Nyquist plots were recorded, as displayed in Fig. 5c. The impedance spectra exhibit two distinct parts including a semicircle in the high-frequency region and a sloped line in the low-frequency region. The $R_{\mathrm{ct}}$ resistance can be estimated from the semicircle diameter of the high-frequency loop while ion diffusion is characterized by the linear part of the sloped line. It is clearly seen that both the electrodes feature a low $R_{\mathrm{ct}}$ and a relatively high slope of impedance plot, revealing good electrochemical activity and ion diffusion in the electrodes [20]. The stored charges in both cathode and anode at various current densities are compared in Fig. 5d, from which we can learn the overall performance of each electrode and determine whether the resulting full cell will behave well. As can be seen, the two electrodes are almost matched, which store approximate charge quantities at similar current densities, indicating comparable rate capability.

Fig. 6a shows the $\mathrm{CV}$ curves of the fabricated $\mathrm{NiO} /$ $\mathrm{Bi}_{2} \mathrm{O}_{3} @ \mathrm{C}$ cell at the scan rates from 5 to $200 \mathrm{mV} \mathrm{s}^{-1}$. Well defined redox couples were observed, corresponding to the overall reaction in the $\mathrm{Ni} / \mathrm{Bi}$ battery: $6 \mathrm{NiO}+3 \mathrm{H}_{2} \mathrm{O}$ $+\mathrm{Bi}_{2} \mathrm{O}_{3} \leftrightarrow 6 \mathrm{NiOOH}+2 \mathrm{Bi}$. Fig. $6 \mathrm{~b}$ presents the typical discharge curves of the assembled $\mathrm{Ni} / \mathrm{Bi}$ battery at different discharge rates. It can be seen that with the increase of the current 64 times from 0.57 to $36.57 \mathrm{~A} \mathrm{~g}^{-1}$, the device still keeps $34 \%$ of the initial capacity, demonstrating good rate capability. Fig. $6 c$ illustrates the Ragone plot of gravimetric energy density versus power density of our device, in which previous data are also included for comparison $[35,36]$. Encouragingly, our $\mathrm{Ni} / \mathrm{Bi}$ battery delivers an energy density of $34.29 \mathrm{~W} \mathrm{~h} \mathrm{~kg}^{-1}$ at a power density of $329 \mathrm{~W} \mathrm{~kg}^{-1}$ while still keeps $6.77 \mathrm{~W} \mathrm{~h} \mathrm{~kg}^{-1}$ at $12,159.8 \mathrm{~W} \mathrm{~kg}^{-1}$, which are considerably higher than those of many previously reported aqueous thin-film energy storage devices such as $\mathrm{Bi}_{2} \mathrm{O}_{3}|| \mathrm{MnO}_{2}$ (11.3 $\mathrm{W} \mathrm{h} \mathrm{kg}^{-1}$ at $352.6 \mathrm{~W} \mathrm{~kg}^{-1}$ ) [37], and even comparable or superior to some non-aqueous hybrid devices, such as $\mathrm{Nb}_{2} \mathrm{O}_{5}-\mathrm{CNT} \| \mathrm{AC}\left(40 \mathrm{~W} \mathrm{~h} \mathrm{~kg}^{-1}\right.$ at $\left.20 \mathrm{~W} \mathrm{~kg}^{-1}\right)$ [38], AC||LTP HEC (14 W h kg at $\left.44 \mathrm{~W} \mathrm{~kg}^{-1}\right)$ [39] and $\mathrm{TiO}_{2}(\mathrm{~B}) \| \mathrm{CNT}\left(13 \mathrm{~W} \mathrm{~h} \mathrm{~kg}^{-1}\right.$ at $300 \mathrm{~W} \mathrm{~kg}^{-1}$ ) [40]. The cycling behavior of our $\mathrm{Ni} / \mathrm{Bi}$ battery at a constant rate is
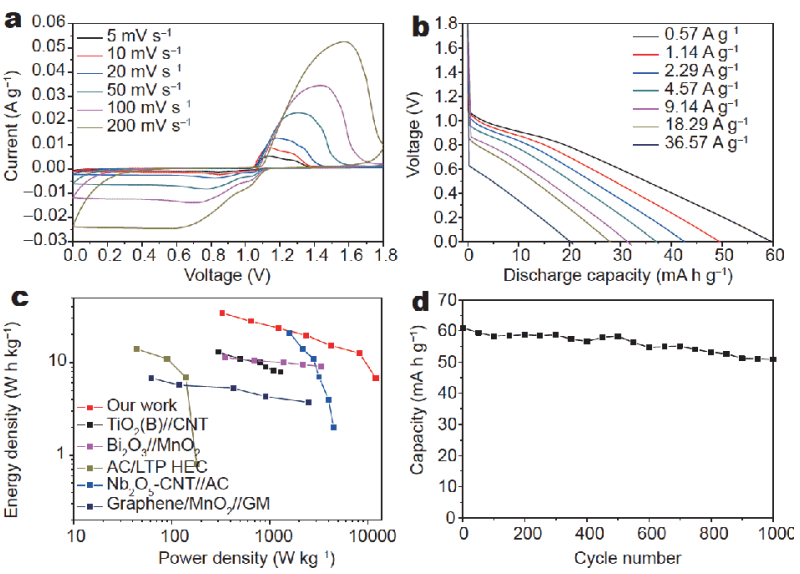

Figure 6 (a) CV curves, (b) typical discharge curves, (c) Ragone plot and (d) cycle performance of the Ni/Bi battery. 
further shown in Fig. $6 \mathrm{~d}$. About $83 \%$ of the initial capacity is retained after 1,000 cycles, demonstrating good cycling stability.

\section{CONCLUSIONS}

In summary, we have reported the facile synthesis of binder-free $\mathrm{Bi}_{2} \mathrm{O}_{3}$ and $\mathrm{NiO}$ electrodes for rechargeable $\mathrm{Ni} / \mathrm{Bi}$ battery with excellent electrochemical performances. After modification with the conductive nanocarbon, $\mathrm{Bi}_{2} \mathrm{O}_{3}$ nanoflake electrode exhibits good cycling performance, rate performance and a high specific capacity of $120 \mathrm{~mA} \mathrm{~h} \mathrm{~g}^{-1}$. The enhanced electrochemical properties can be attributed to the fast charge transfer kinetics benefited from the binder-/additive-free electrode architecture and the carbon matrix decoration. The resulting $\mathrm{Ni} / \mathrm{Bi}$ battery manifests a high energy density of $34.29 \mathrm{~W} \mathrm{~h} \mathrm{~kg}^{-1}$ and a high power density of $12,159.8 \mathrm{~W} \mathrm{~kg}^{-1}$ as well as excellent cycling stability $(1,000$ cycles with $83 \%$ retention). The good electrochemical performances coupled with the facile preparation of the $\mathrm{Ni} / \mathrm{Bi}$ battery suggest its potential application in thin-film energy storage devices.

\section{Received 25 June 2018; accepted 19 July 2018; published online 10 September 2018}

1 Cheng F, Liang J, Tao Z, et al. Functional materials for rechargeable batteries. Adv Mater, 2011, 23: 1695-1715

2 Gong M, Li Y, Zhang H, et al. Ultrafast high-capacity NiZn battery with NiAlCo-layered double hydroxide. Energy Environ Sci, 2014, 7: 2025

3 Zhang K, Hu Z, Tao Z, et al. Inorganic \& organic materials for rechargeable Li batteries with multi-electron reaction. Sci China Mater, 2014, 57: 42-58

4 An C, Liu X, Gao Z, et al. Filling and unfilling carbon capsules with transition metal oxide nanoparticles for Li-ion hybrid supercapacitors: towards hundred grade energy density. Sci China Mater, 2017, 60: 217-227

$5 \mathrm{Xu} \mathrm{D}, \mathrm{Mu} \mathrm{C}$, Wang B, et al. Fabrication of multifunctional carbon encapsulated $\mathrm{Ni@NiO} \mathrm{nanocomposites} \mathrm{for} \mathrm{oxygen} \mathrm{reduction,}$ oxygen evolution and lithium-ion battery anode materials. Sci China Mater, 2017, 60: 947-954

6 Wang G, Fu L, Zhao N, et al. An aqueous rechargeable lithium battery with good cycling performance. Angew Chem Int Ed, 2007, 46: $295-297$

7 Qu Q, Fu L, Zhan X, et al. Porous $\mathrm{LiMn}_{2} \mathrm{O}_{4}$ as cathode material with high power and excellent cycling for aqueous rechargeable lithium batteries. Energy Environ Sci, 2011, 4: 3985

8 Zeng $\mathrm{Y}$, Lin Z, Wang Z, et al. In situ activation of 3D porous Bi/ carbon architectures: toward high-energy and stable nickel-bismuth batteries. Adv Mater, 2018, 30: 1707290

9 Ke X, Zhang Z, Cheng $\mathrm{Y}$, et al. $\mathrm{Ni}(\mathrm{OH})_{2}$ nanoflakes supported on 3D hierarchically nanoporous gold/Ni foam as superior electrodes for supercapacitors. Sci China Mater, 2017, 61: 353-362

10 Xia Y, Yang Y, Shao H. Differences in the effects of Co and CoO on the performance of $\mathrm{Ni}(\mathrm{OH})_{2}$ electrode in $\mathrm{Ni} / \mathrm{MH}$ power battery. J Power Sources, 2011, 196: 495-503

11 Wang $\mathrm{H}$, Liang $\mathrm{Y}$, Gong $\mathrm{M}$, et al. An ultrafast nickel-iron battery from strongly coupled inorganic nanoparticle/nanocarbon hybrid materials. Nat Commun, 2012, 3: 917

12 Yang B, Yang Z, Wang R. Facile synthesis of novel two-dimensional silver-coated layered double hydroxide nanosheets as advanced anode material for Ni-Zn secondary batteries. J Power Sources, 2014, 251: 14-19

13 Ahlberg E, Palmqvist U, Simic N, et al. Capacity loss in Ni-Cd pocket plate batteries. The origin of the second voltage plateau. J Power Sources, 2000, 85: 245-253

14 Sarma B, Jurovitzki AL, Smith YR, et al. Redox-induced enhancement in interfacial capacitance of the titania nanotube/bismuth oxide composite electrode. ACS Appl Mater Interfaces, 2013, 5: $1688-1697$

15 Gujar TP, Shinde VR, Lokhande CD, et al. Electrosynthesis of $\mathrm{Bi}_{2} \mathrm{O}_{3}$ thin films and their use in electrochemical supercapacitors. J Power Sources, 2006, 161: 1479-1485

16 Wang HW, Hu ZA, Chang YQ, et al. Facile solvothermal synthesis of a graphene nanosheet-bismuth oxide composite and its electrochemical characteristics. Electrochim Acta, 2010, 55: 8974-8980

17 Yuan D, Zeng J, Kristian $\mathrm{N}$, et al. $\mathrm{Bi}_{2} \mathrm{O}_{3}$ deposited on highly ordered mesoporous carbon for supercapacitors. Electrochem Commun, 2009, 11: 313-317

18 Senthilkumar ST, Selvan RK, Ulaganathan M, et al. Fabrication of $\mathrm{Bi}_{2} \mathrm{O}_{3} \| \mathrm{AC}$ asymmetric supercapacitor with redox additive aqueous electrolyte and its improved electrochemical performances. Electrochim Acta, 2014, 115: 518-524

19 Zeng Y, Lin Z, Meng Y, et al. Flexible ultrafast aqueous rechargeable Ni||Bi battery based on highly durable single-crystalline bismuth nanostructured anode. Adv Mater, 2016, 28: 9188-9195

20 Sun J, Li Z, Wang J, et al. $\mathrm{Ni} / \mathrm{Bi}$ battery based on $\mathrm{Ni}(\mathrm{OH})_{2}$ nanoparticles/graphene sheets and $\mathrm{Bi}_{2} \mathrm{O}_{3}$ rods/graphene sheets with high performance. J Alloys Compd, 2015, 643: 231-238

21 Sun J, Wang J, Li Z, et al. Assembly and electrochemical properties of novel alkaline rechargeable $\mathrm{Ni} / \mathrm{Bi}$ battery using $\mathrm{Ni}(\mathrm{OH})_{2}$ and $(\mathrm{BiO})_{4} \mathrm{CO}_{3}(\mathrm{OH})_{2}$ microspheres as electrode materials. J Power Sources, 2015, 274: 1070-1075

22 Yuan P. Electrode behaviors of $\mathrm{BiFeO}_{3}$ powders: a possible application of $\mathrm{Bi}_{2} \mathrm{O}_{3}$ oxide in rechargeable battery. Int J Electrochem Sci, 2017, 12: 3686-3696

23 Liu J, Jiang J, Cheng $\mathrm{C}$, et al. $\mathrm{Co}_{3} \mathrm{O}_{4}$ nanowire@ $\mathrm{MnO}_{2}$ ultrathin nanosheet core/shell arrays: a new class of high-performance pseudocapacitive materials. Adv Mater, 2011, 23: 2076-2081

24 de Jong $\mathrm{M}$, Meijerink $\mathrm{A}$, Gordon $\mathrm{RA}$, et al. $\mathrm{Is}_{\mathrm{Bi}^{2+}}$ responsible for the red-orange emission of bismuth-doped $\mathrm{SrB}_{4} \mathrm{O}_{7}$ ? J Phys Chem C, 2014, 118: 9696-9705

25 Peng M, Wondraczek L. Photoluminescence of $\mathrm{Sr}_{2} \mathrm{P}_{2} \mathrm{O}_{7}: \mathrm{Bi}^{2+}$ as a red phosphor for additive light generation. Opt Lett, 2010, 35 : 2544-2546

26 Huang $\mathrm{Y}, \mathrm{Li} \mathrm{Y}, \mathrm{Hu} \mathrm{Z}$, et al. A carbon modified $\mathrm{MnO}_{2}$ nanosheet array as a stable high-capacitance supercapacitor electrode. J Mater Chem A, 2013, 1: 9809

27 Zuo W, Xu P, Li Y, et al. Direct growth of bismuth film as anode for aqueous rechargeable batteries in $\mathrm{LiOH}, \mathrm{NaOH}$ and $\mathrm{KOH}$ electrolytes. Nanomaterials, 2015, 5: 1756-1765

28 Zuo W, Zhu W, Zhao D, et al. Bismuth oxide: a versatile highcapacity electrode material for rechargeable aqueous metal-ion batteries. Energy Environ Sci, 2016, 9: 2881-2891 
29 Zhao Z, Ye Y, Zhu W, et al. Bismuth oxide nanoflake@carbon film: A free-standing battery-type electrode for aqueous sodium ion hybrid supercapacitors. Chin Chem Lett, 2018, 29: 629-632

30 Qu D, Wang L, Zheng D, et al. An asymmetric supercapacitor with highly dispersed nano- $\mathrm{Bi}_{2} \mathrm{O}_{3}$ and active carbon electrodes. J Power Sources, 2014, 269: 129-135

31 Ci S, Wen Z, Qian Y, et al. NiO-microflower formed by nanowireweaving nanosheets with interconnected $\mathrm{Ni}$-network decoration as supercapacitor electrode. Sci Rep, 2015, 5: 11919

32 Zhang $\mathrm{Y}$, Wang J, Wei $\mathrm{H}$, et al. Hydrothermal synthesis of hierarchical mesoporous $\mathrm{NiO}$ nanourchins and their supercapacitor application. Mater Lett, 2016, 162: 67-70

33 Xiao H, Qu F, Wu X. Ultrathin $\mathrm{NiO}$ nanoflakes electrode materials for supercapacitors. Appl Surf Sci, 2016, 360: 8-13

34 Liu J, Chen M, Zhang L, et al. A flexible alkaline rechargeable $\mathrm{Ni}$ / Fe battery based on graphene foam/carbon nanotubes hybrid film. Nano Lett, 2014, 14: 7180-7187

35 Simon P, Gogotsi Y. Materials for electrochemical capacitors. Nat Mater, 2008, 7: 845-854

36 Christen T, Carlen MW. Theory of Ragone plots. J Power Sources, 2000, 91: 210-216

$37 \mathrm{Xu} \mathrm{H}, \mathrm{Hu} \mathrm{X}$, Yang $\mathrm{H}$, et al. Flexible asymmetric micro-supercapacitors based on $\mathrm{Bi}_{2} \mathrm{O}_{3}$ and $\mathrm{MnO}_{2}$ nanoflowers: larger areal mass promises higher energy density. Adv Energy Mater, 2015, 5: 1401882

38 Wang X, Li G, Chen Z, et al. High-performance supercapacitors based on nanocomposites of $\mathrm{Nb}_{2} \mathrm{O}_{5}$ nanocrystals and carbon nanotubes. Adv Energy Mater, 2011, 1: 1089-1093

39 Aravindan V, Chuiling W, Reddy MV, et al. Carbon coated nano$\mathrm{LiTi}_{2}\left(\mathrm{PO}_{4}\right)_{3}$ electrodes for non-aqueous hybrid supercapacitors. Phys Chem Chem Phys, 2012, 14: 5808-5814

40 Wang Q, Wen Z, Li J. A hybrid supercapacitor fabricated with a carbon nanotube cathode and a $\mathrm{TiO}_{2}-\mathrm{B}$ nanowire anode. $\mathrm{Adv}$ Funct Mater, 2006, 16: 2141-2146

Acknowledgements This work was supported by grants from the National Natural Science Foundation of China (51672205), the National Key R\&D Program of China (2016YFA0202602) and the Research StartUp Fund from Wuhan University of Technology.

Author contributions $\mathrm{Ba} D$ and Sun Y performed the experiments; Ba D wrote the paper with support from Li Y, Guo Z and Liu J. All authors contributed to the general discussion.

Conflict of interest The authors declare no conflict of interest. 


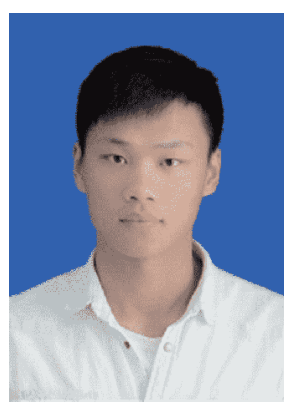

Deliang Ba received his BE degree in electronic science and technology from Beijing University of Technology in 2016. He is now studying for his Master's degree at Huazhong University of Science \& Technology. His research interest focuses on the preparation and modification of electrode materials for sodium ion batteries, aqueous batteries and supercapacitors.
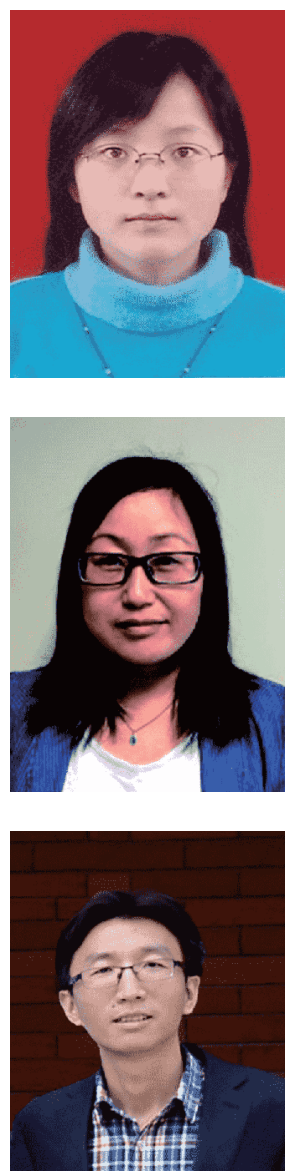

Yuanyuan Li received her MSc and PhD degrees from the Department of Physics, Central China Normal University, China. She has been a faculty at the School of Optical and Electronic Information, Huazhong University of Science and Technology, China since April, 2010 and is now an Associate Professor. Her research interest includes the synthesis of semiconducting metal oxide nanostructures and their applications in electrochemical energy storage (supercapacitors \& batteries) and solar water splitting.
Zaiping Guo received her PhD in materials engineering from the University of Wollongong in December 2003. After APD fellowship in the Institute for Superconducting \& Electronic Materials, she joined the Faculty of Engineering and Information Sciences, University of Wollongong as a Lecturer in 2008, and was promoted to Professor in 2012, and then Senior Professor in 2013. Her current research interest focuses on the design and application of nanomaterials for energy storage and conversion, including rechargeable batteries, hydrogen storage, and fuel cells.
Jinping Liu received his PhD degree from the Central China Normal University (CCNU) in June 2009. During the period of 2008-2011, he did visiting and post-doctoral research at Nanyang Technological University (NTU) in Singapore. He is currently Chair Professor at Wuhan University of Technology. The research interest in Dr. Liu's group includes the nanostructures synthesis and their electrochemical applications (batteries, supercapacitors \& electrocatalysis).

\title{
直接生长纳米结构电极构建高功率和高稳定性的碱性镍/铋电池
}

\author{
巴德良 ${ }^{1}$, 李园园 ${ }^{1,2^{*}}$, 孙云飞 ${ }^{1}$, 郭再萍 $^{2^{*}}$, 刘金平 $^{3^{*}}$
}

摘要 氧化铋 $\left(\mathrm{Bi}_{2} \mathrm{O}_{3}\right)$ 作为碱性镍/铋电池的负极材料, 因其理论容量高、易制备而受到广泛关注. 然而, 金属氧化物普遍较差的导电性以及 氧化铋的循环不稳定性严重限制了器件的性能. 本文用直接生长的具有动力学优势的氧化铋纳米片薄膜作为镍/铋电池的负极; 同时将葡 萄糖衍生的碳包覆在纳米片的表面, 不仅促进了电子传递, 还缓冲了氧化铋转换反应过程中的体积膨胀, 有助于维持电极的循环稳定性. 该 $\mathrm{Bi}_{2} \mathrm{O}_{3} @ \mathrm{C}$ 电极表现出高比容量, 优异的倍率性能(在6.7 s内充满电) 以及良好的循环稳定性(约 1200 次; 每圈仅衰减 $0.011 \%$ ). 与氧化镍 $(\mathrm{NiO})$ 纳米片阵列正极搭配, 组装的完全无粘结剂的碱性镍/铋电池展现出 $34.29 \mathrm{~W} \mathrm{~h} \mathrm{~kg}$ 的最大能量密度和 $12159.8 \mathrm{~W} \mathrm{~kg}$ 的最大功率密 度以及良好的循环性能; 其功率密度甚至远远优于许多混合/非对称型超级电容器. 本研究展现了新一代薄膜镍/铋电池在高功率电子器 件应用上的巨大潜力. 